$1-1-1964$

\title{
Marketing of lumber through retail outlets in West Virginia
}

Donald E. Nelson

Follow this and additional works at: https://researchrepository.wvu.edu/ wv_agricultural_and_forestry_experiment_station_bulletins

\section{Digital Commons Citation}

Nelson, Donald E., "Marketing of lumber through retail outlets in West Virginia" (1964). West Virginia Agricultural and Forestry Experiment Station Bulletins. 500.

https://researchrepository.wvu.edu/wv_agricultural_and_forestry_experiment_station_bulletins/466 @ WVU. It has been accepted for inclusion in West Virginia Agricultural and Forestry Experiment Station Bulletins by an authorized administrator of The Research Repository@WVU. For more information, please contact ian.harmon@mail.wvu.edu. 



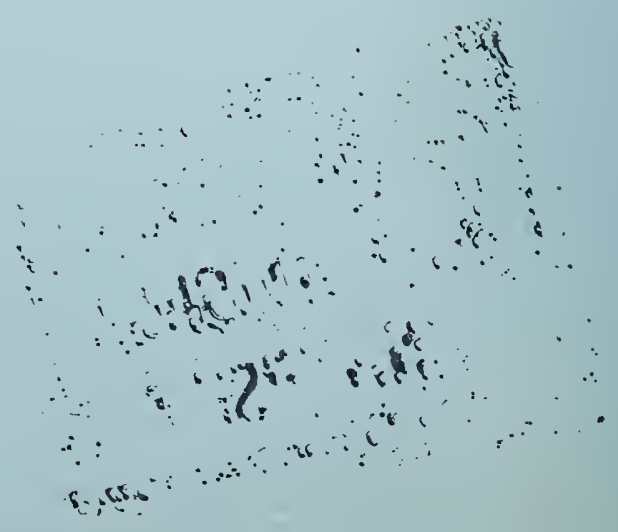




\section{AG-ENG LIBRARY WEST VIRGINIA UNIVERSITY}

Marketing of Lumber

Through Retail Outlets In West Virginia

WEST VIRGINIA UNIVERSITY AGRICULTURAL EXPERIMENT STATION 


\section{THE AUTHOR}

The author of Marketing of Lumber Through Retail Outlets in West Virginia is Donald E. Nelson, instructor in Wood Technology, Division of Forestry, West Virginia University. Mr. Nelson is now working on his doctorate in forestry at the University of Michigan, Ann Arbor.

West Virginia University

Agrigultural Experiment Station

College of Agriculture, Forestry, and Home Economics

A. H. VanLandingham, Director

MORGANTOWN 
Marketing of Lumber Through Retail Outlets in West Virginia

DONALD E. NELSON

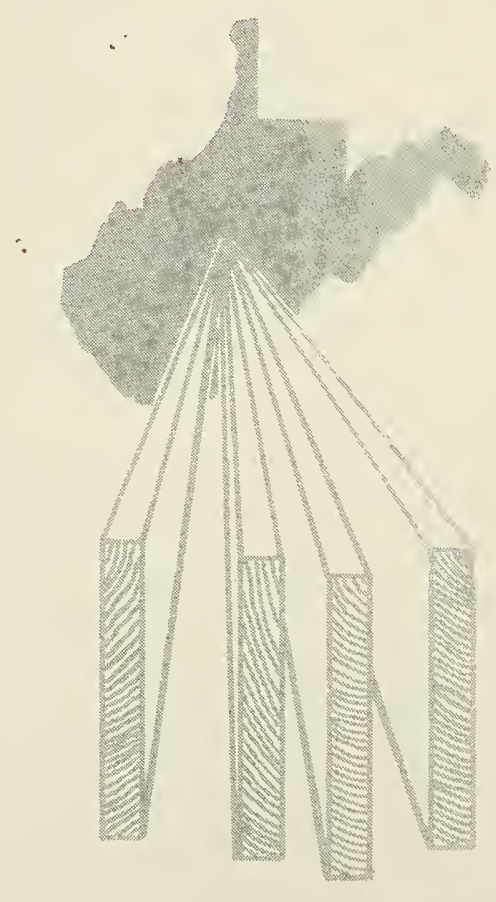

West Virginia University Agricultural Experiment Station 
Digitized by the Internet Archive in 2010 with funding from Lyrasis Members and Sloan Foundation 


\section{CONTENTS}

PAGE

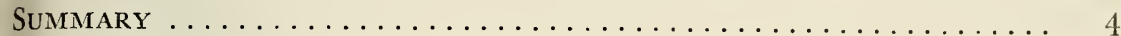

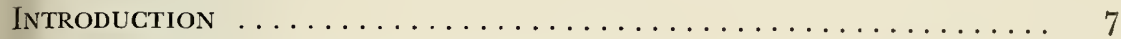

General Characteristics of Firms $\ldots \ldots \ldots \ldots \ldots \ldots \ldots \ldots \ldots$

Lumber Procured for Resale $\ldots \ldots \ldots \ldots \ldots \ldots \ldots \ldots \ldots \ldots \ldots .10$

Reasons Given for Purchasing Lumber from a Specific Region . . 14

Product Transformations by Retailers $\ldots \ldots \ldots \ldots \ldots \ldots \ldots .17$

Products Sold in Addition to Lumber .................. 18

Lumber Sold by Grade, Thickness, and Region Produced ....... 21

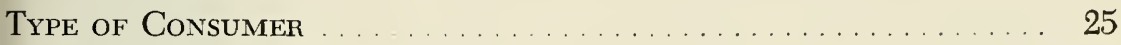

Species Carried in Stock . . . . . . . . . . . . . . . . . . . . . 29

Form and Condition of Lumber When Sold . . . . . . . . . . . 32

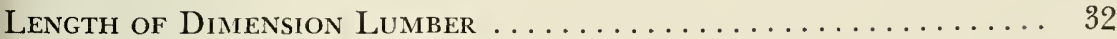

Services Available to Customers $\ldots \ldots \ldots \ldots \ldots \ldots \ldots \ldots$

Use of Credit and Delivery Service by Customers $\ldots \ldots \ldots \ldots \ldots$

General Comments $\ldots \ldots \ldots \ldots \ldots \ldots \ldots \ldots \ldots \ldots \ldots$

Conclusions 


\section{SUMMARY}

THIS REPORT on practices of West Virginia lumber retailers is basec upon information gathered in face-to-face interviews. It is one in : series of forest products marketing studies conducted by the Divisior of Forestry at West Virginia University. This report applies only tc West Virginia, but the data gathered is also part of a cooperative re gional project involving Northeastern states. A regional report on mar. keting practices of lumber retailers in the Northeast is in preparation

Most retail lumber is marketed through firms classified as SIC \#5211, Retail Yards, and SIC \#5212, Building Materials dealers. The estimated 275 firms in these classes were divided into size class groups according to number of employees. Large firms employed over 20 workers, medium-sized firms employed from 10 to 20 , small firms employed from 5 to 9 , and very small firms employed less than 5 workers. Total employment in retail lumber in West Virginia is estimated to be more than 3,000.

Gross sales of these firms for 1961 amounted to $\$ 100$ million, of which one-third was lumber. Non-lumber wood products accounted for additional sales; sales of all wood products (including lumber) totaled over one-half of the gross sales.

Although West Virginia produced 300 million feet of hardwood lumber in 1961, only 12 million entered into the retail lumber trade. Hardwoods are not well-suited for house construction. Over 200 million feet of softwood lumber, primarily from the West, was distributed through retailers in West Virginia in 1961. Considerable volumes of Southern softwoods were also included.

The primary reasons given for preferring Western lumber were quality of manufacture, greater margin of profit, acceptable moisture content, and buyer's specifications. Southern lumber was preferred by some builders for sheathing and heavy joists, and because it was available in truckload lots on short order. Retailers were generally well satisfied with hardwoods purchased locally, but they complained about poorly manufactured and poorly seasoned local softwoods.

Most retailers resold the lumber without transforming it in any way. A few, however, surfaced or dried lumber before selling it.

The variety of products sold by retailers is indicative of the growing merchandising trend which attempts to offer one-stop shopping for the home builder. Nearly all firms that sold lumber in West Virginia also sold plywood, hardboard, hardware, paint, flooring, and other products.

About two-thirds of the lumber was dimension lumber (nominal two inches and thicker) and 80 per cent of this came from the Twest. 
The other one-third was boards; most of this was also Western lumber, but 40 per cent was Southern pine boards.

The home owner was the most important customer, buying about half the lumber sold. Building contractors bought 40 per cent, and industry bought the rest. The homeowner was particularly important to the very small firm.

The species most commonly stocked by retailers, but not necessarily in large volumes, were: oak, Southern pine, ponderosa-lodgepole pine, redwood, Western white pine, Douglas-fir, and birch-maple. The most common species of dimension lumber were: Douglas-fir, Western spruce, Western fir (true fir), Western hemlock, redwood, Southern pine, and Canadian spruce. The larger firms carried a greater variety of species than the smaller firms.

The Western lumber was usually sold in kiln-dried condition, whereas Southern and local softwoods were usually sold in air-dried condition. Much of the hardwood lumber was sold in rough form, but virtually all of the softwood lumber was sold in the dressed form.

Sellers of retail lumber offered numerous services to help their customers decide what products to buy, and to assist them in using the products. Some rented or loaned tools to customers. Retailers extended credit on about one-half of their sales. They delivered about 80 per cent of the lumber they sold, although some of them charged for clelivery.

Lumber is becoming less important to many dealers. They often devote more promotion to other products, particularly those products that have a higher mark-up than lumber. Price competition and unrestricted wholesaling have in some instances all but eliminated the retailers, especially when relatively large volumes of lumber are involved. To counteract these trends, some retailers have gone into the construction business themselves, selling entire homes rather than just the lumber to build them. Other retailers have aimed their promotion efforts at the amateur handyman, who still relies heavily upon the retail yards to furnish materials for do-it-yourself projects, home remodeling, repairs, and additions.

Houses are now being built in more efficient ways, resulting in less housing lumber going through the retailer. Large contractors construct entire subdivisions, for which they buy wholesale lumber. Economyminded families may buy factory pre-cut houses, which they can erect themselves. Others may buy pre-fabricated or factory-built houses from large-scale manufacturing firms. These trends in housing tend to circumvent the lumber retailer.

The building materials dealer of the future will need to move forward with modern merchandising techniques in order to survive. Retailing in general, and lumber retailing in particular, is becoming more 
and more competitive. The retailer will need to emphasize more and more the services he can offer his customers. He must not disregard the housewife or handyman who only wants a single board or a pound of nails. Tomorrow this customer may buy a truckload of these materials. 


\section{Marketing of Lumber Through Retail Outlets in West Virginia}

\section{Introduction}

DONALD E. NELSON

THE LUMBER RETAILER is one link in the lumber-marketing chain. This bulletin presents marketing information gathered in face-to-face interviews with West Virginia lumber retailers. Data for the calendar year 1961 were gathered by field interviews conducted in the summer of 1962.

Some published information for retail lumber marketing is contained in a 1955 National Survey, ${ }^{1}$ and in various trade publications. The 1955 National survey was analyzed only by major areas of the country-the Northeast, the North Central, the South, and the West. Although this survey attempted to cover every fifth retail yard, nearly half of the yards did not reply to the mail questionnaire.

Another source of information about retail lumber yards is the periodic Census of Business. The most recent data available are for the calendar year 1958." These data show that, for the nation, eight million sales employees were engaged in retail sale of all products. Over 200,000 of these were employed in the lumber and building material retail trade. All retailers collectively sold nearly $\$ 200$ billion worth of proclucts; retail lumber and building materials accounted for over $\$ 7$ billion dollars. This amounts to 3.6 per cent of total retail sales.

Since retailers sell directly to consumers, it follows that retail businesses will locate primarily in areas of high population. Such areas have been defined by the Bureau of the Census as Standard Metropolitan Areas. The largest of these is the New York Metropolitan area, which contained 853 retail lumber and building materials establishments, according to the 1958 Census of Business. The same census gives data for the one small Standard Metropolitan Area which lies entirely within West Virginia. Parts of three additional Standard Metropolitan Areas are within the State. All, however, are relatively small in population.

1. National Retail Lumber Dealers Association. 1955. Survey Among hetail Jumbel Dealers, S.E.P. \$194, sponsored jointly by National Retail Lumber Dealers Association and The Saturday Evening Post, Curtis Publishing Company.

21958 Census of Business, I'ol. 1, Retail trade-Summary Statistics. 


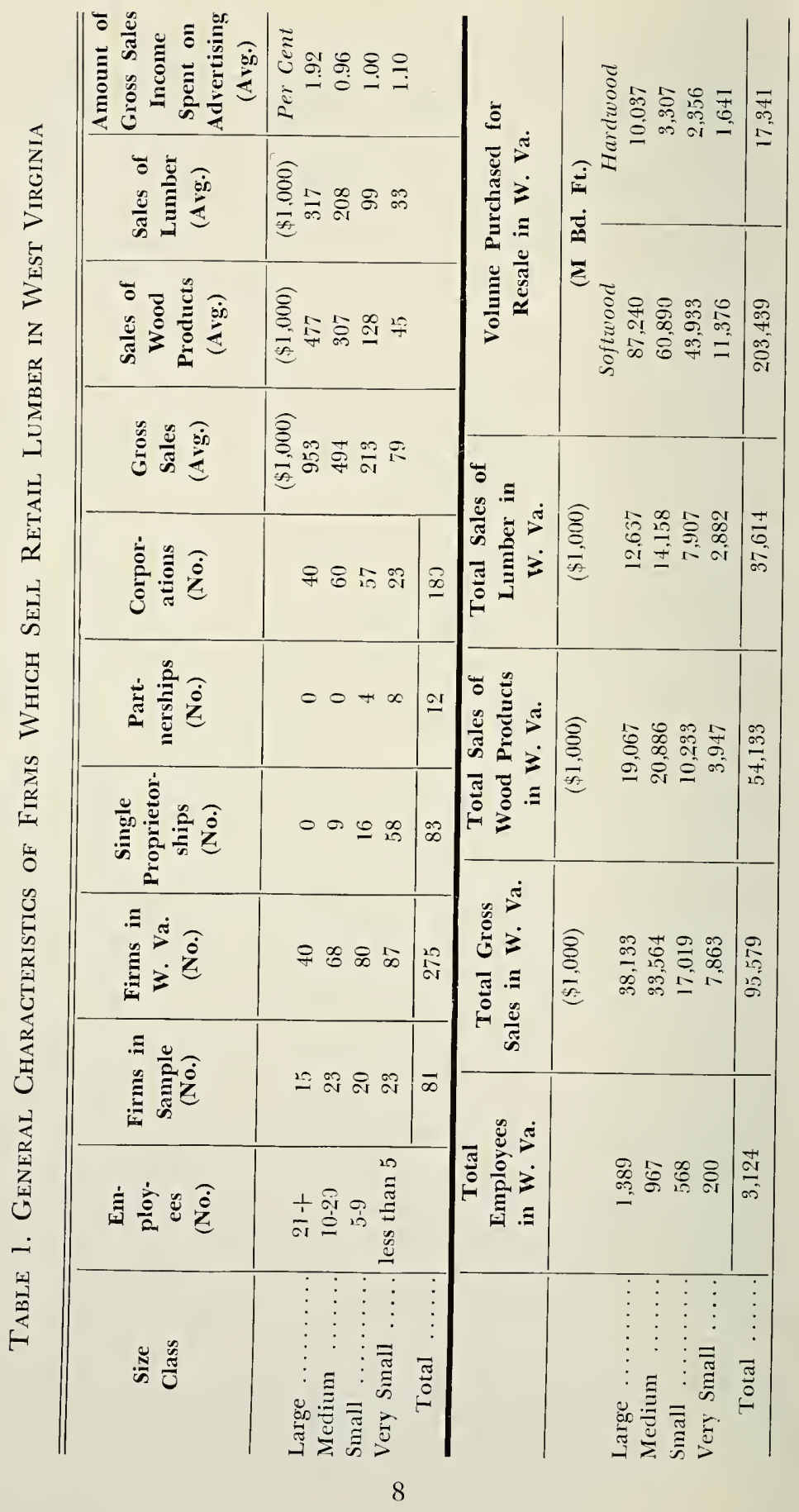


The Charleston Metropolitan area contained 20 retail lumber outlets in 1958; the Steubenville-Weirton area contained 31; the Wheeling area 43; and the Hutington-Ashland area contained 37. Thus, a total of 131 retailers of lumber are located in those Stanclard Metropolitan Areas serving West Virginia urban areas. Other retail lumber outlets are located in rural areas throughout the State. The census reports a total of 289 retail yards and building materials dealers in West Virginia in 1958. The present study estimates there were 275 firms in operation in 1961. However, some of these firms operated more than one retail establishment.

Data were collected in 1962 from firms engaged in the sale of retail lumber in West Virginia. The data presented in this bulletin apply to the calendar year 1961. They were gathered in face-to-face interviews with the managers or owners of 81 of the estimated 275 firms in business in 1961. Additional data were gathered by mail questionnaires from some firms not sampled in face-to-face interviews. Although returns were not complete, enough additional information was available to make a reasonable estimate of the total number of firms, and the size class of these firms. The basic data gathered from the 81 firms were then expanded to apply to all 275 firms by use of appropriate blow-up factors for the various employee-size classes.

\section{General Characteristics of Firms}

The firms included in this study were classified according to number of employees. It was recognized from the beginning that this was not a perfect classification, since there was no assurance that the number of employees had any definite relationship to the amount of lumber sold. Many of these employees were engaged in varying degrees in the sale of products other than lumber, such as hardware, paint, plywood, millwork, aluminum or other non-wood siding, hardboard, flooring, cement block, glass, and others. Some firms even employed carpenters who worked full time at house construction.

The number of employees was used for classification because this was the most reliable figure obtained in the face-to-face interviews. Most interviewees were not able to, or did not care to, state accurately the volume of lumber sold, total sales, length of dimension lumber sold, region in which the lumber was produced, etc. However, it is reasonable to assume that the estimates they made, when taken collectively, come close to the actual quantities.

Table 1 lists some general characteristics of firms that sell retail lumber in West Virginia; most are corporations. Firms with less than five employees, however, were predominately single proprietorships. The 
large firms averaged almost $\$ 1$ million gross sales, of which one-third was lumber. Lumber contributed over 40 per cent of the total sales of those firms having less than twenty-one employees.

Lumber retailers do not advertise extensively. The large firms indicated their advertising expenditures approached 2 per cent of gross sales. The rest of the firms indicated their advertising expenditures rotaled about 1 per cent of gross sales.

Horizontal or vertical integration" was not highly developed in the retail lumber trade in West Virginia. Not many firms were horizontally integrated, and very few of those that were operated more than two retail yards. A few firms were vertically integrated in that they purchased and resold building sites, constructed homes for customers, dealt in real estate, insurance, etc. But these were the exception rather than the rule. Most firms consisted of a single-yard location, and restricted their operation to retailing building products.

A revolution of a sort is taking place in lumber retailing, however. Most firms have been forced to offer a more or less complete line of building materials to their customers. Some firms have emphasized other building materials to the extent that they are not concerned about the sale of lumber. For these firms, lumber is just a product which must be stocked in order to attract customers. Other building materials are often emphasized by sellers of retail lumber because of the change in the manner in which houses are now built. Formerly, a house was built by a carpenter employed by a potential homeowner. Now, the common practice is for a contractor to build an entire sub-division, then sell the houses outright. On a large-scale operation like this, the contractor usually buys lumber wholesale in carload or truckload lots. He may depend upon the retailer only for other building materials, specialty items, etc. Because of these trends, retailers are selling proportionally less lumber and proportionally more of some other types of building materials. In addition, lumber is losing out to some competitive materials in certain applications.

\section{Lumber Procured for Resale}

Sellers of retail lumber either purchase the lumber which they sell, produce lumber for retail sale, or have it produced for them under contract. Over 99 per cent of the lumber procured by West Virginia retailers was purchased by them. The fraction not purchased was almost entirely hardwood, produced by some local mill under contract to the retailer.

3An example of horizontal integration is a chain of lumber yards. An example of vertical integration is a sawmill, planing mill, wholesale yard, retail yard, and other related firms, all under one managenient. 

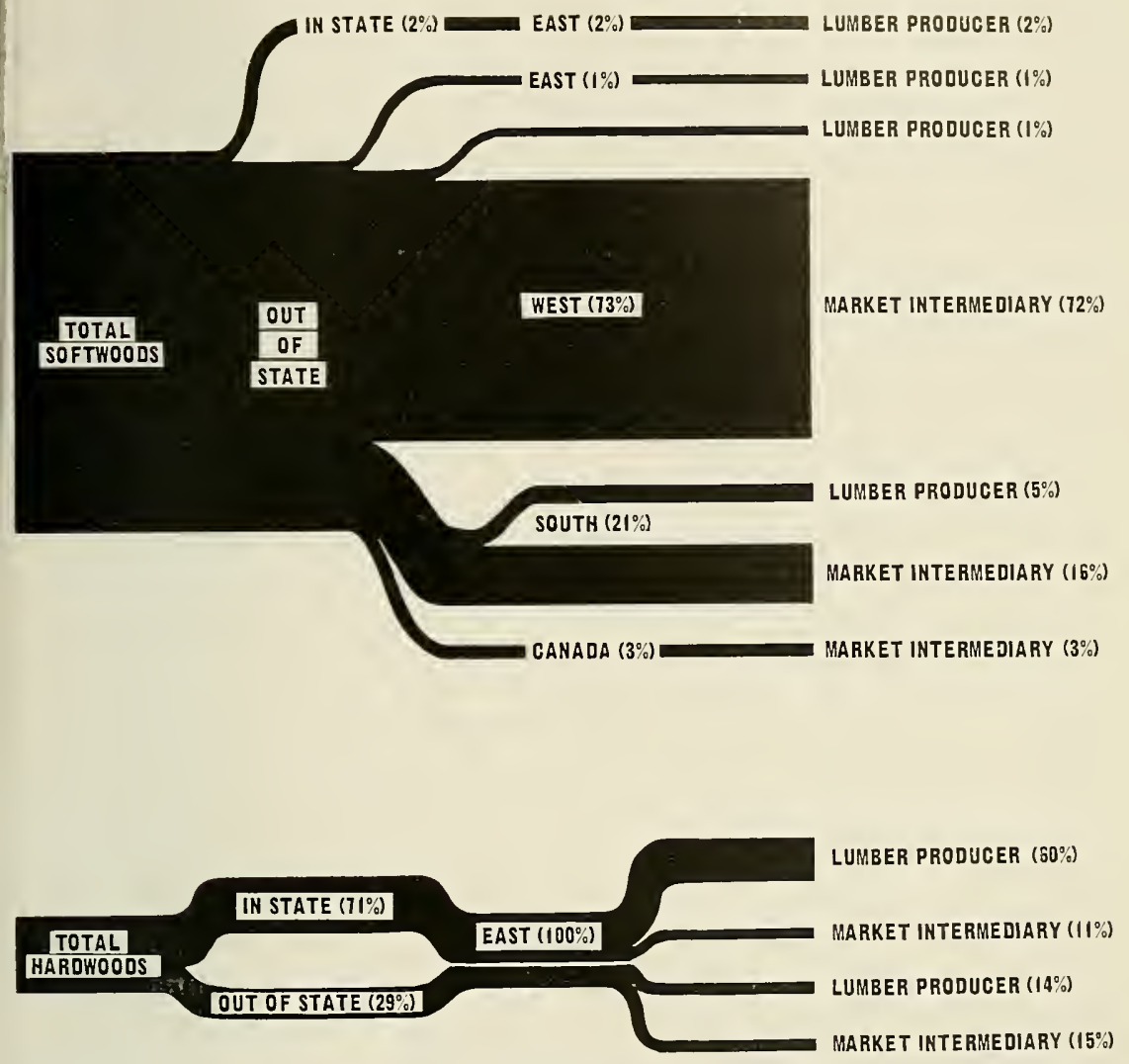

FIGURE 1. Volume of lumber purchased for resale by retailer, by region produced, and by seller.

Figure 1 shows the purchase of lumber by retailers for resale. Retailers purchased almost 220 million feet of lumber for resale in 1961. Table 2 shows the breakdown. Only 17 million feet of this was hardwood lumber, hardwoods being of limited use in the building trades. All of the hardwood lumber came from the Eastern region of the United States. Although West Virginia produces and exports large volumes of hardwood lumber to surrounding states, almost one-third of the hardwood lumber purchased by WTest Virginia retailers came from out-ofstate. Therefore, less than 12 million feet of the nearly 300 million feet of hardwood lumber produced in West Virginia in $1961^{\text {t }}$ entered into

\pm U.S. Bureau of Census, Current Industrial Report. 1962. Lumber Production and Mill Stocks, 1961 Series, M24T (61)-I, Washington 25, D.C. 


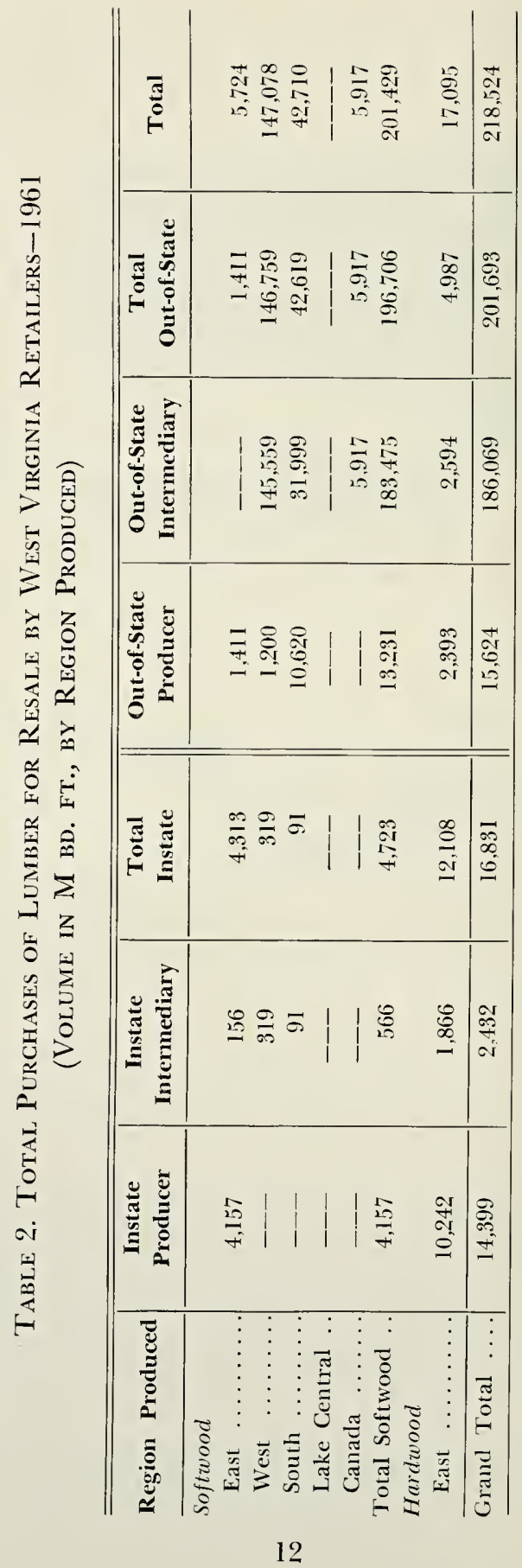


the State's retail lumber trade. This merely points out the minor role of hardwood lumber in the building trades. Most hardwood lumber goes into manufactured products, rather than house construction.

In this study, hardwood flooring was not included as hardwood lumber. If hardwood flooring had been included, the amount of hardwood used in house construction would have been increased considerably, since 97 per cent of the firms indicated that they sold flooring.

Over 200 million feet of softwood lumber was purchased for resale by retailers in 1961. Only 2 per cent of this had been produced in West Virginia. Ninety-seven per cent had been produced outside of the Eastern region, with the West producing three-fourths of the total volume purchased by West Virginia retailers. The South produced about onefifth, and Canada produced 3 per cent. It is likely that Canada actually produced a higher percentage than the study indicated, but buyers of wholesale lumber are not always certain of the geographical area in which the lumber was produced. Some Canadian-produced lumber is undoubtedly listed under Western, since Canada produced about 13 per cent of the total softwood consumed in the United States in $1961 .^{5}$

Nearly all of the softwood lumber was purchased for resale through dealings with out-of-state market intermediaries. An exception was the small volume of softwood lumber produced within West Virginia; it was normally purchased directly from the producer. About one-fourth of the Southern lumber obtained by West Virginia retailers was purchased directly from the lumber producer, without dealing through a market intermediary.

Most of the instate hardwood lumber handled by lumber retailers was purchased directly from a producer. Over one-half of the out-of-state hardwood lumber was purchased through a market intermediary.

Softwood lumber was usually delivered to retail yards in West Virginia by rail, whereas hardwood lumber was delivered mainly by truck. Softwood lumber in carload lots accounted for 80 per cent of all the softwood delivered to retail yards. Most softwood lumber rail shipments originated in the West. Considerable volumes of Southern softwoods were purchased in truckload lots by retail yards. This was particularly true for the smaller yards, which found the smaller volumes per load and rapid delivery to their liking. Buying Western softwoods in less than carload lots is often prohibitively expensive. This is one reason why the smaller retail yards purchased proportionately more Southern softwoods than the larger firms.

5Lea, Sperry. 1962. The U.S. Softurood Lumber Situation in a Canadian-American Perspective, Canadian-American Committee (U.S.A.) and Private Planning Association of Canada, p. 2. 


\section{Reasons Given for Purchasing Lumber From a Specific Region}

The purchasers of lumber for resale were asked in an open-end question to give the reasons why they purchased.lumber from various regions of the country. Their answers were fitted, when possible, into an existing list of possible factors. Where more than one reason was given, the reasons were listed in order of importance. Often the open-end answers were negative in form, for example, "I purchase Western lumber because Southern lumber doesn't come in long enough lengths." In this situation, the negative answer would be converted into a positive statement of why Western lumber was preferred-because it was available in clesired size and length.

The reasons given are listed below in order of importance. The percentage given indicates the proportion of firms that listed a factor as one of the reasons why they purchased lumber from a region:

\section{Reason Per Cent}

1. Availability .............. 92

2. Margin of profit ............ 74

3. Other* ............... 60

4. Homeowners' specifications ...... 40

5. Quality of manufacture ......... 38

6. Contractor's specifications ....... 31

7. Special uses $\ldots \ldots \ldots \ldots \ldots \ldots .26$

8. Moisture content $\ldots \ldots \ldots \ldots \ldots, 18$

9. Appearance $\ldots \ldots \ldots \ldots \ldots \ldots \ldots, 15$

10. Conformance to grade ......... 14

11. General physical factors ........ 10

12. Strength specifications $\ldots \ldots \ldots \ldots, 10$

13. Volume available in certain grades .. 9

14. Sizes available, and lengths ....... 9

15. Architect's specifications ....... 6

16. Weathering ability $\ldots \ldots \ldots \ldots \ldots .4$

17. Building codes $\ldots \ldots \ldots \ldots \ldots \ldots$.

* "Other" is broken down further and discussed on page 12.

Different reasons naturally were given for buying lumber from the Eastern, the Western, or the Southern regions. Lumber produced in the Eastern region, mostly Appalachian hardwoods, was readily available to the retailer. Additional factors frequently mentioned were greater margin of profit, higher quality of manufacture, and homeowners' specifications. 
Factors which most often influenced retailers to purchase Western lumber were quality of manufacture, greater profit margins, acceptable moisture content, and contractors' and homeowners' specifications.

Southern lumber was preferred by retail firms for specialty uses; it was widely used for sheathing and large joists. "Most of the houses in this area were constructed of Southern pine, so the owners want Southern pine for alterations and repairs." And, "Southern pine in $2 \times 8$ 's and $2 \times 10$ 's is stronger than Western lumber, so contractors in this area prefer it for heavy joists." Other reasons given were availability, margin of profit, contractors' and homeowners' specifications, and availability in small truckload lots with rapid delivery.

Although not apparent from these answers, some yards did not stock lumber from certain regions because some producers did not protect the retailer's dealership. "We formerly sold local softwoods at our yard, but as soon as the local sawmiller saw this, he became our competitor, and he undersold us. Now we only stock Western Iumber, and stress quality of manufacture."

"When a contractor builds a house in this area he buys a truckload of Southern pine lumber at wholesale prices. For this reason, we don't stock Southern pine anymore. Almost anyone can buy it now at the wholesale price. The producer himself is our biggest competitor."

The reason frequently given for stocking Canadian lumber was price. Canadian spruce was satisfactory (where building codes permit its use) and lower in price than competitive materials. Some retailers claimed that they did not want to sell Canadian lumber, but they were forced to do so when the competition began to undersell them.

Under miscellaneous "other" reasons, one or more firms were influenced to buy Western lumber for the following reasons:

Quality of the material itself, old growth, narrow rings, soft texture.

Straight lumber.

Holds its shape.

Workability.
Variety of species with important properties, such as redwood with decay resistance.

Variety of colors available.

Experience with certain reliable mills.

"Other" reasons for preferring Southern pine were:

For use as subfloor.

Available in small lots.

Available on short order.

For use as finish lumber with clear

finishes.

For certain industrial uses.

For crating for overseas shipment.
For cheap construction.

For use as siding.

Because of superior nailholding power.

For construction of concrete forms.

Because it is stronger than Douglasfir. 
Some additional reasons given for buying Eastern lumber were:

Best quality available.

Lower freight rate to yard.
For use as sheathing

(yellow poplar).

To keep money in West Virginia.

An additional comment relative to softwood lumber in West Virginia was that kiln-dried native softwoods were hard to obtain in the State. Most retail lumber dealers felt that native hardwoods were well manufactured, but native softwoods were not. One dealer pointed to a bin containing West Virginia hemlock $2 \times$ 4's purchased locally. It was obvious that a large proportion of these studs were miscut. Often the softwood dimension material was produced by a small mill which lacked surfacing equipment and dry kilns. The product produced was therefore not similar to the Western product, and was not competitive with it.

Some West Virginia retail lumber dealers found that local softwoods were highly satisfactory in house construction. One dealer stated that the carpenters in his area preferred local hemlock to Western lumber. Local building codes and FHA-insured housing loans sometimes prevent the use of local species, since they are not usually grade-marked or stress-rated.

The attitudes of building contractors and architects toward softwood lumber as produced locally vs. Western softwoods were examined by Brock $^{6}$ in New England. The criticisms of Northeastern softwoods by building contractors were very similar to the criticisms of West Virginia softwoods by retailers.

How strong an influence is the lumber retailer in deciding what kinds of lumber are to be used for house construction in a given area? Many dealers indicated that homeowners', contractors', or architects' specifications influenced them to purchase lumber for a certain area. But many customers who know nothing about wood rely on the retailer's judgment as to the best species to use. Often the customer must use the kind of lumber stocked or recommended by the retailer. For example, one retailer stated that he sold only Western red cedar for framing lumber. He stressed to his customers the natural resistance to decay and the dimensional stability of Western red cedar, while perhaps ignoring the low strength and poor nail-holding properties of that species. It is certain that this dealer greatly influenced the type of lumber used in that area. Western red cedar is suitable, but not normally preferred for house framing, because of low strength, low nail-withdrawal resistance,

${ }^{6}$ Brock, Samuel M. 1963. Marketing Maine Lumber to the Northeastern Building Construction Industry, Bulletin 615, Maine Agricultural Experiment Station, September, 1963. 
and low modulus of elasticity. ${ }^{7}$ This is an example of the retailer's preference influencing the customer, rather than the customer's preference influencing the retailer.

In all probability there is not a strong consumer preference toward a certain species of softwood lumber. Perhaps the customers in this one area of West Virginia now demand Western red cedar because they are satisfied with its performance, but in most areas of the State it is not even stocked by yards. If customers are allowed to select from several species, most will buy the lowest priced species. Professional builders and carpenters are more likely to select a species on the basis of its known properties rather its price.

\section{Product Transformations by Retailers}

The retail lumber dealer usually resells the product in the same form as he bought it. His main functions have been assembling the materials, displaying them to the customers, taking orders for them, and delivering them to the building site. In addition, progressive retailers often provide a variety of merchandising services such as demonstrations, self-service, outside salesmen, store display space, plans and planning service, financing arrangements, contractor services, how-todo-it information, equipment rental, and free estimates. All of the above services do not change the form of the product.

Certain product transformations are performed by retailers on the lumber they purchase. Proper undercover storage protects lumber from exposure. All of the firms in the study stored at least 25 per cent of the purchased lumber under cover, and three-fourths stored all of their purchased lumber under cover. A few firms handled part of the lumber without storage; this would imply direct delivery to the job site without going through the retail yard at all.

Less than one-fourth of the retailers seasoned the lumber they purchased; the others bought already seasoned lumber, or sold green lumber. Air-drying was the common seasoning operation performed for those dealers who did season lumber. A few retail yards arranged to have lumber kiln-ctried after purchasing it, but most yards which sold such lumber bought it in that condition.

TWestern red cedar framing lumber is not stress graded. Decking of this species is stress rated, however, and the values for select "DEX" grade are given as 900 P.S.I. extreme fiber in bending and 1.10 million P.S.I. modulus of elasticity. By comparison, values for Douglas-fir are 1,500 P.S.I. in bending, and 1.76 million P.S.I. modulus of elasticity. Southern pine decking is rated at 1,750 P.S.I. and 1.76 million P.S.I. modulus of elasticity. Data from Table 1, National Design Specifications for StressGrade Lumber and Its Fastenings, 1962 edition, National Lumber Manufacturers Association. 
None of the yards surveyed did any grade marking of their own, although many bought grade-marked lumber for resale to their customers. None of the yards in the survey graded any lumber; they either purchased graded lumber, or sold ungraded lumber.

Almost half of the yards finished or surfaced a small per cent of the lumber they handled. Over half did not surface lumber at all, but almost all yards did cut lumber to special sizes if desired by the customer. The facilities available for re-working lumber varied from a hand cross-cut saw to a complete woodworking shop.

Size of firm had an effect upon product transformations performed by retailers. The small firms purchased a larger proportion of local limber, which was often green and rough. For this reason the small firms were more likely to air dry lumber. Also, smaller firms which were large enough to afford a surfacer were more likely to purchase and surface local lumber. Larger firms did not air dry or surface much lumber, rather they purchased it in the form they wished to sell it. The lumber they did surface was mostly for special thicknesses or for special products.

\section{Products Sold in Addition to Lumber}

Only those retailers who sold lumber were included in this sample. Over the years, lumber retailers have increased the number and variety of products sold until today many offer a complete "supermarket" of building materials. Many dealers now stock any merchandise which their past customers have demanded consistently. Thus lumber yards have become building materials yards, and the variety of products is continually increasing.

Not too many years ago, the buyer of a new home expected and received nothing more than four walls, a roof, a few small windows, a couple of doors, and a stairway, with a few partitions and perhaps a front porch.

Then came gas and electrical installations, running water, and central heating of a primitive kind. Today, in addition to all that, the owner of a new home expects insulation, weather stripping, automatic heat control, electrical outlets on every wall of every room, fully equipped bathrooms and kitchens, and a host of other extras-called luxuries not long ago. That is the way housing has improved in the continuing effort to meet the public demand.

Exactly the same sort of evolution has taken place in the retail lumber and building materials industry. The industry and its members have kept abreast or ahead of the times, steadily adjusting and expanding their services to give the public better value and extra service at minimum cost. 8

West Virginia lumber dealers were asked what products they sold in addition to lumber. The listing below gives the percentage of yards handling the products listed:

8National Retail Lumber Dealers Association. 1952, Inside the Retail Lumber and Building Materials Industry, N.R.L.D.A., the Ring Building, Washington, D. C. 
Plywood

Reconstituted wood products

(hardboard, particle board) ..... 97

Hardware ................... 97

Paint .................... 97

Flooring $\ldots \ldots \ldots \ldots \ldots \ldots \ldots \ldots \ldots \ldots$

Clapboard and shingles $\ldots \ldots \ldots \ldots \ldots, 91$

Non-wood exterior siding ......... 79

Other products ............... 84

A wide variety of other products was sold by lumber retailers. Dealers were asked to list the other products which contributed significantly to the operation of their firm. Other building materials frequently mentioned were:

Cement

Concrete block

Plaster

Roofing materials and metal roofing

Brick

Ready-mix concrete

Gravel

Sand

Stone

Wall board
Glass

Glass block

Floor tile

Wall tile

Ceiling tile and insulation board

Steel beams

Assembled roof trusses

Gutters

Wallpaper

Insulation

Other products frequently mentioned reflect the growing "onestop shopping" trend in retail lumber firms:

Electrical wiring and fixtures

Plumbing and fixture

Gas appliances

Electrical appliances

Kitchen cabinets

Furnaces

Sewer pipe and tile

Ornamental iron

Yard and garden tools

Fencing

Furniture

Lime
Insurance

Building sites

Pre-cut homes

Pre-hung doors

Well drilling

Farm machinery

Mine wedges

Coal and oil

Chain saws

Feed

Septic tanks 
Naturally, the larger firms were able to stock a wider variety of merchandise than the smaller ones, but even those retailers with less than five employees maintained a surprisingly large variety of merchandise. Often the selection was not as large within a class of products; for example, the small yard might stock only one species of hardwood flooring, rather than the five or six species commonly stocked by large yards. But most yards stocked nearly all the materials needed to build a complete house.

The increasing number and kinds of products handled by retail yards have created some problems. A larger inventory and increased selling space are often needed. Formerly, when lumber was the main product sold, a retailer could handle all sales from a small office, since there was no need to display lumber to the customers. Not so with many of the other products; the customers want to see the lawn mowers, bath tubs, kitchen cabinets, and other products before buying. Customers expect the sales personnel to be able to answer any questions about price, installation, maintenance, and durability of all these additional products. Manufacturers who sell products to retail yards assist in educating the retail sales personnel about the product. They hope this will help further the sale of the product.

Marketing of new products through lumber dealers was discussed hy Gene C. Brewer, president of United States Plywood, as being a vital step in the success of a new product.

Another aspect of marketing which has presented very thorny problems for us [manufactures] and for others is in getting our products to the customer.

... our solution to the distribution problem was to make the lumber dealer realize the profit potential ultimately involved.

We made three promises to the dealer:

(1) We'll work together to make money for you.

(2) We will continue to work together to make money for you.

(3) We will do these things by helping you to build store traffic and by showing you how to turn that traffic into sales.

Through sustained integrated sales promotion and advertising programs backed by consistent personal contact by our sales force, we made those promises good. 9

Many manufacturers and trade associations attempt to influence sales of the particular product in which they have a financial interest. This merchandising at the manufacturer's level, combined with manufacturer's and trade association advertising, helps to sell the diverse products handled by retail yards. In some cases, mass advertising has pre-sold the customer before he eyer contacts the retailer. But often the knowledge of the various products comes from the retailer's sales force,

${ }^{9}$ Brewer, G. C. 1963. "Wood Merchandising in a Competitive Market," Forest Products Journal, January, 1963, pp. 12A-14A. 
which will range from well- to poorly-informed on the relative merits of a particular product. With the wide diversity of products handled, maintaining a well-trained sales force is a major problem of the retailer.

Merchandising has recently become such an important part of the lumber retailers' operation that the retailers' themselves are making a concerted effort to do something about it, rather than rely upon the manufacturers. In November, 1962, the National Lumber and Building Materials Dealers Association underwrote a merchandising program intended to coorclinate the efforts of dealers, wholesalers, and manufacturers. This was described as the most ambitious merchandising program in the history of the industry. ${ }^{10}$ Known as HAPI (Home and Property Improvement Program), this year-long promotional service depicts retail lumber yards as one-stop remodeling centers for homeowners. It trains dealers, through merchandising programs, to present the type of service and products which customers want, rather than the traditional product mix. In this way, retailers hope to recapture some of their lost sales.

Table 3 presents summary data from the firms surveyed, showing the relative contribution of lumber, and all wood products toward the gross sales of the firms. Sales of all products per employee averaged about $\$ 30,000$, of which well over half was wood products, which includes lumber. Somewhat less than half of the total sales volume was attributed to lumber. The large firms in particular sold a smaller proportion of lumber and wood products. The mark-up of other products is usually higher than the mark-up for lumber. This may partially explain the smaller gross sales per employee of the large firms; often selling other products is more profitable. Average lumber sales per employee was about 70 thousand board feet of lumber per year, most of which was softwood.

Although other products are being sold by retail lumber clealers at an increasing rate, lumber is still a major item for most retailers.

\section{Lumber Sold by Grade, Thickness, and Region Produced}

Figure 2 shows lumber sold to customers by grade and region produced. Two broad catagories of lumber are boards and dimension. In this study, all lumber that was a nominal two inches or thicker was considered to be dimension. About two-thirds of the lumber was dimension.

10"Retail Lumber Group Sets Merchandising Program to Boost Building Materials Sales," Advertising Age, February 19, 1962, p. 71. 
Boards were separated into four grade classifications:

Grade 1

Grade 2

Grade 3

Grade 4
Softwoods

Hardwoods

Softwoods

Hardwoods

Softwoods

Hardwoods
Clear

Selects and better

$\# 1$ and \#2 common

\#1 common

\#3 common and poorer

\#2 common and poorer

All species ungraded or millrun or nonstandard grades.

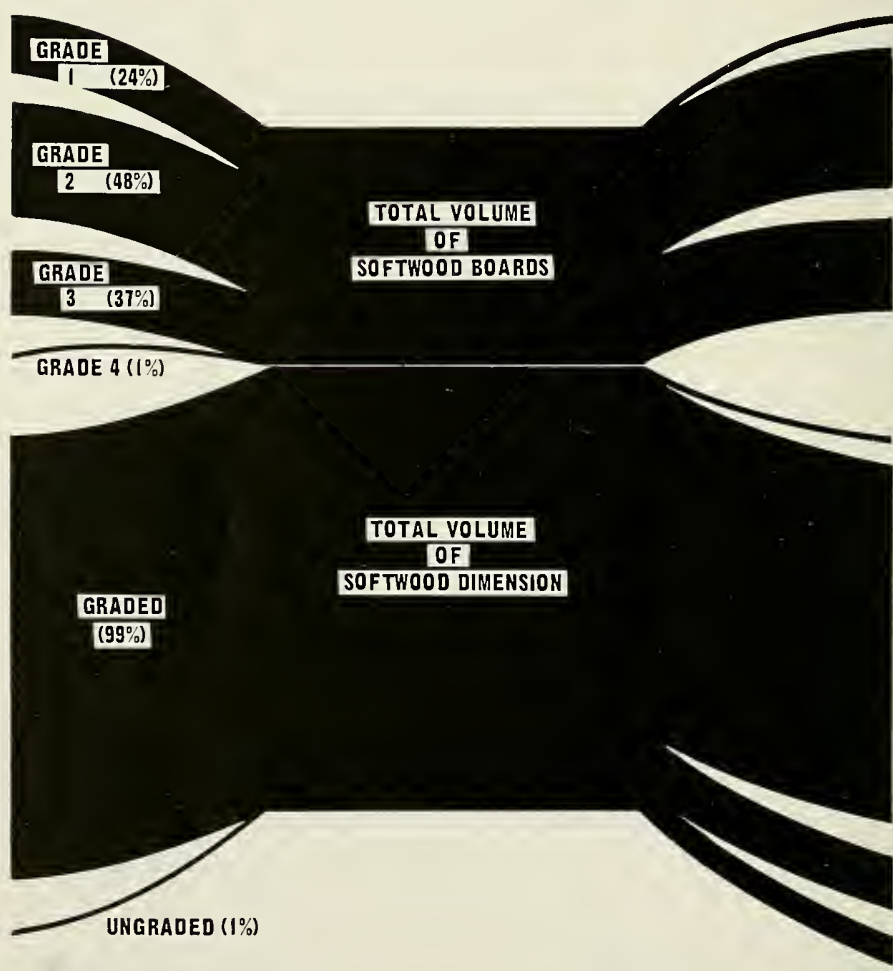

EASTERN ( $3 \%)$

WESTERN $(58 \%)$

SOUTHERN (39\%)

EASTERN ( $2 \%)$

WESTERN $(80 \%)$

SOUTHERN ( $12 \%)$

CANADIAN (6\%)

GRADE

I $(46 \%)$

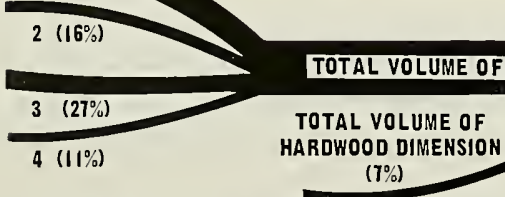

EASTERN (100\%)

FIGURE 2. Grade and region produced of hardwood and softwood boards and dimension lumber. 
Table 3. Retall Lumber Yards in West Virginia-1961

(Maximum, Average, and Minimum Sales in Dollars and in Board Feet, by Size Class of Firms)

\begin{tabular}{|c|c|c|c|c|c|c|c|c|c|}
\hline \multirow{2}{*}{$\begin{array}{l}\text { Size of } \\
\text { Firms }\end{array}$} & \multicolumn{3}{|c|}{$\begin{array}{c}\text { Gross Sales } \\
\text { per Firm }\end{array}$} & \multicolumn{3}{|c|}{ Sales of Wood } & \multicolumn{3}{|c|}{$\begin{array}{c}\text { Sales of Lumber } \\
\text { Per Firm }\end{array}$} \\
\hline & \multicolumn{3}{|c|}{$(\$ 1,000)$} & \multicolumn{3}{|c|}{$(\$ 1,000)$} & Max. & $(\$ 1,000)$ & Min. \\
\hline Large ....... & 3,500 & 477 & 150 & 1,200 & 953 & 250 & 800 & 317 & 75 \\
\hline Medium .... & 1,000 & 494 & 150 & 800 & 307 & 75 & 500 & 208 & 25 \\
\hline Small .. & 350 & 213 & 75 & 250 & 128 & 25 & 150 & 99 & 25 \\
\hline \multirow[t]{2}{*}{ Very Small .. } & 150 & 79 & 25 & 75 & 45 & 12 & 75 & 33 & 10 \\
\hline & \multicolumn{3}{|c|}{$\begin{array}{l}\text { Gross Sales } \\
\text { per Employee } \\
(\$ 1,000)\end{array}$} & \multicolumn{3}{|c|}{$\begin{array}{c}\text { Sales of Wood Products } \\
\text { per Employee } \\
(\$ 1,000)\end{array}$} & \multicolumn{3}{|c|}{$\begin{array}{l}\text { Sales of Lumber } \\
\text { per Employee } \\
(\$ 1,000)\end{array}$} \\
\hline Large ....... & \multicolumn{3}{|c|}{27.2} & \multicolumn{3}{|c|}{18.6} & \multicolumn{3}{|c|}{9.0} \\
\hline Medium & \multicolumn{3}{|c|}{35.2} & \multicolumn{3}{|c|}{21.9} & \multicolumn{3}{|c|}{14.8} \\
\hline Small .... & \multicolumn{3}{|c|}{30.4} & \multicolumn{3}{|c|}{18.3} & \multicolumn{3}{|c|}{14.1} \\
\hline Very Small & \multicolumn{3}{|c|}{34.3} & \multicolumn{3}{|c|}{19.6} & \multicolumn{3}{|c|}{14.3} \\
\hline
\end{tabular}

\section{Employees per \\ Firm}

\section{Sales of Softwood}

Lumber per Firm

(M Bd. Ft.)
Sales of Hardwood

Lumber per Firm

(M Bd. Ft.)

\begin{tabular}{lrrrrrrrrr}
\hline & Max. & Av. & Min. & Max. & Av. & Min. & Max. & Av. & Min. \\
\hline Large . . . & 120 & 35 & 21 & 10,000 & 2,181 & 375 & 1,000 & 251 & 5 \\
Medium .. & 20 & $\mathbf{1 4}$ & 10 & 4,500 & 895 & 230 & 250 & 49 & 10 \\
Small ... . & 9 & 7 & 5 & 1,950 & 549 & 75 & 100 & 29 & 0 \\
Very Sinall & 4 & 2 & 0 & 600 & 131 & 9 & 200 & 19 & 0 \\
\hline \hline
\end{tabular}

\section{Total Sales of Lumber in Dollars}

Total Sales of Lumber in $\mathrm{M}$ Bd. Ft. (Av. Price per M. Bd. Ft.)
Sales of Softwood

per Employee

(M. Bd. Ft.)
Sales of Hardwood per Employee

(M. Bd. Ft.)

\begin{tabular}{llll}
\hline Large $\ldots \ldots \ldots \ldots \ldots$ & $\$ 145$ & 62.3 & 7.2 \\
Medium $\ldots \ldots \ldots \ldots \ldots$ & $\$ 231$ & 63.9 & 3.5 \\
Small $\ldots \ldots \ldots \ldots \ldots$ & $\$ 180$ & 78.5 & 4.2 \\
Very Small $\ldots \ldots \ldots \ldots$ & $\$ 256$ & 57.0 & 8.3 \\
\hline
\end{tabular}

Almost half of the softwood boards were $\# 1$ and $\# 2$ common grades. These grades are commonly used in the better-built homes for sheathing, roof boards, painted trim, painted shelving, and subflooring.

About one-fourth of the softwood boards were $\# 3$ common and poorer. These grades find use in more economical construction as sheathing, roof boards, subflooring, concrete forms, and low-cost form construction.

Another one-fourth of the softwood boards were of clear or finish grades. This grade is widely used in siding, and for both exterior and 
interior trim. Although the lower grades may be used for painted trim, high-grade painted trim demands clear lumber. Obviously, the clear grades could be used in applications where appearance is not a factor (such as sheathing, subflooring, and roof boards), but this would be a wasteful practice.

Dimension lumber was classified as either graded or ungraded. With the exception of a small amount of Eastern softwood, nearly all dimension had been graded before sale to customers. Dimension is used for house framing; the arerage house contains over 10 thousand feet of lumber, of which over 7 thousand is framing lumber, 2 thousand is sheathing lumber, 300 is siding lumber, and almost 600 is flooring and trim. ${ }^{11}$

West Virginia retailers sold almost twice as much softwood dimension as boards. Eighty per cent of the dimension sold was Western. Most of the boards also were Western species, so almost three-fourths of the total lumber sold was Western lumber.

Half of the boards sold was \#1 and \#2 common. These are sheathing grades; twice as much Southern pine was sold in these grades. This was, however, the only grade of boards in which Southern pine was preferred. Number 2 common is the customary sheathing grade in Southern pine, and is preferred because the knots are not inclined to drop out. Western lumber is preferred for both the clear grades and the \#3 common and poorer.

Differences were relatively minor between the grade of boards sold and region in which produced for the various size firms, as shown in Table 4. The very small firms were the only group that sold more Southern pine boards than other species. No group sold large volumes of Eastern or Canadian boards. Smaller firms tended to sell a higher per cent of Southern pine, partly because it was available in truckload lots.

About 8 per cent of the softwood dimension sold by the very small firms was Eastern lumber. Larger firms sold smaller proportions of Eastern softwood dimension.

Most of the hardwood lumber was boards. The most common grade of hardwood boards sold through lumber dealers was selects and better. This high-grade material is used for interior trim, shelving, and some yellow poplar siding. Over 40 per cent of the hardwood lumber sold by retailers was this grade; however, only 17 million feet of hardwood lumber was sold.

11Fleischer, H. O. 1960. "The Use of Wood in Tomorrow's House." Forest Products Journal, December, 1960, p. 648. 
Low-grade oak boards were used in form construction and as subflooring material. Green oak is reputed to make a fine subflooring material, but FHA construction requirements will not allow its use.

Very little hardwood dimension was sold. Some framing lumber was cut from yellow poplar and basswood. Other thick lumber was sold for truck beds, farm use, and bridge planks. All in all, a very small amount of hardwood lumber goes into the construction of houses.

\section{Type of Consumer}

Retail dealers were asked to estimate the volume of lumber purchased by each of three types of consumers: building contractors, homeowners, and industrial concerns. Almost half of the retailers' lumber sales was to homeowners, 40 per cent was to building contractors, and 11 per cent was to industrial concerns. Figure 3 shows this distribution.

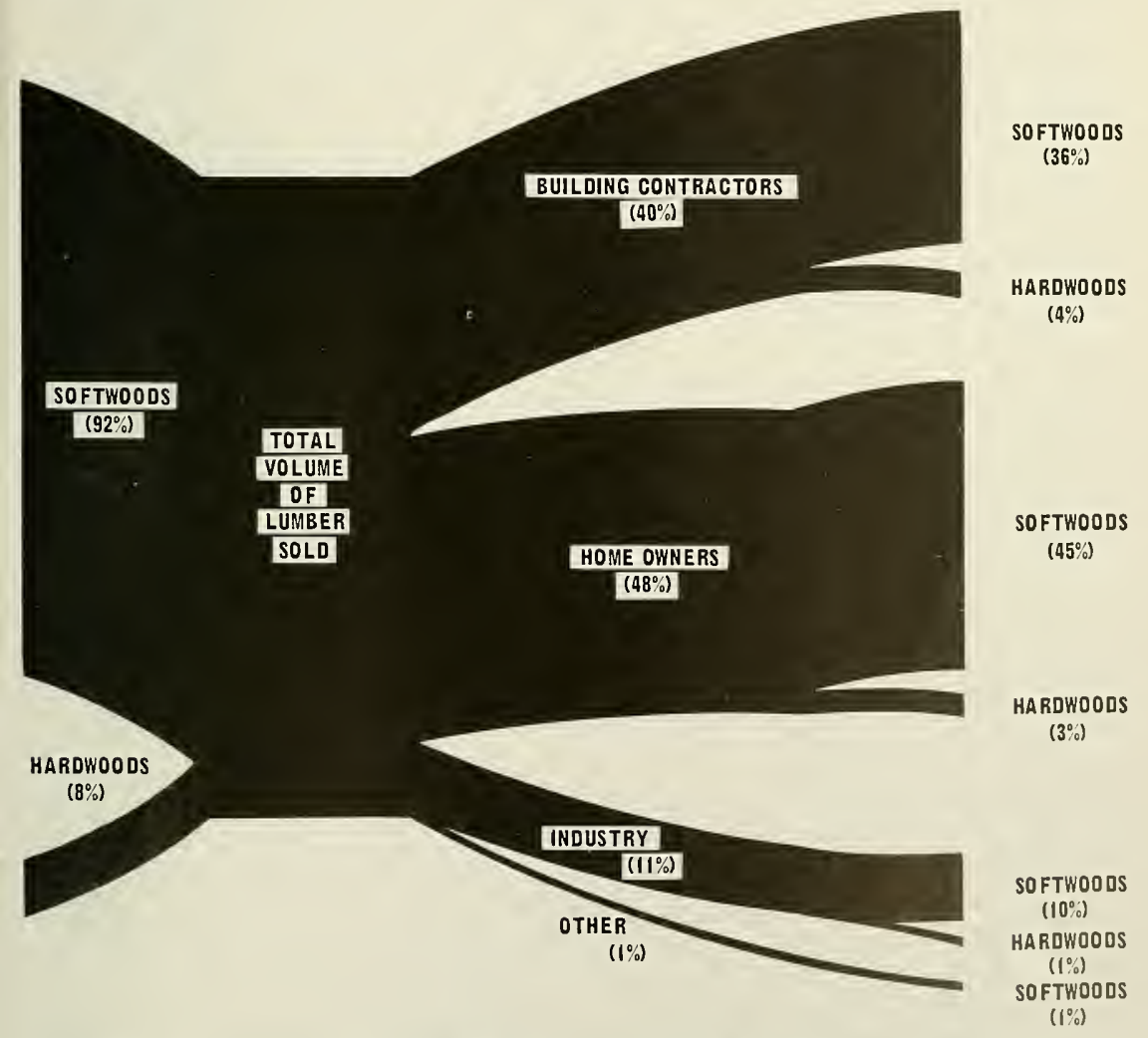

FIGURE 3. Volume of lumber sold by softwoods and hardwoods and by type of customer. 


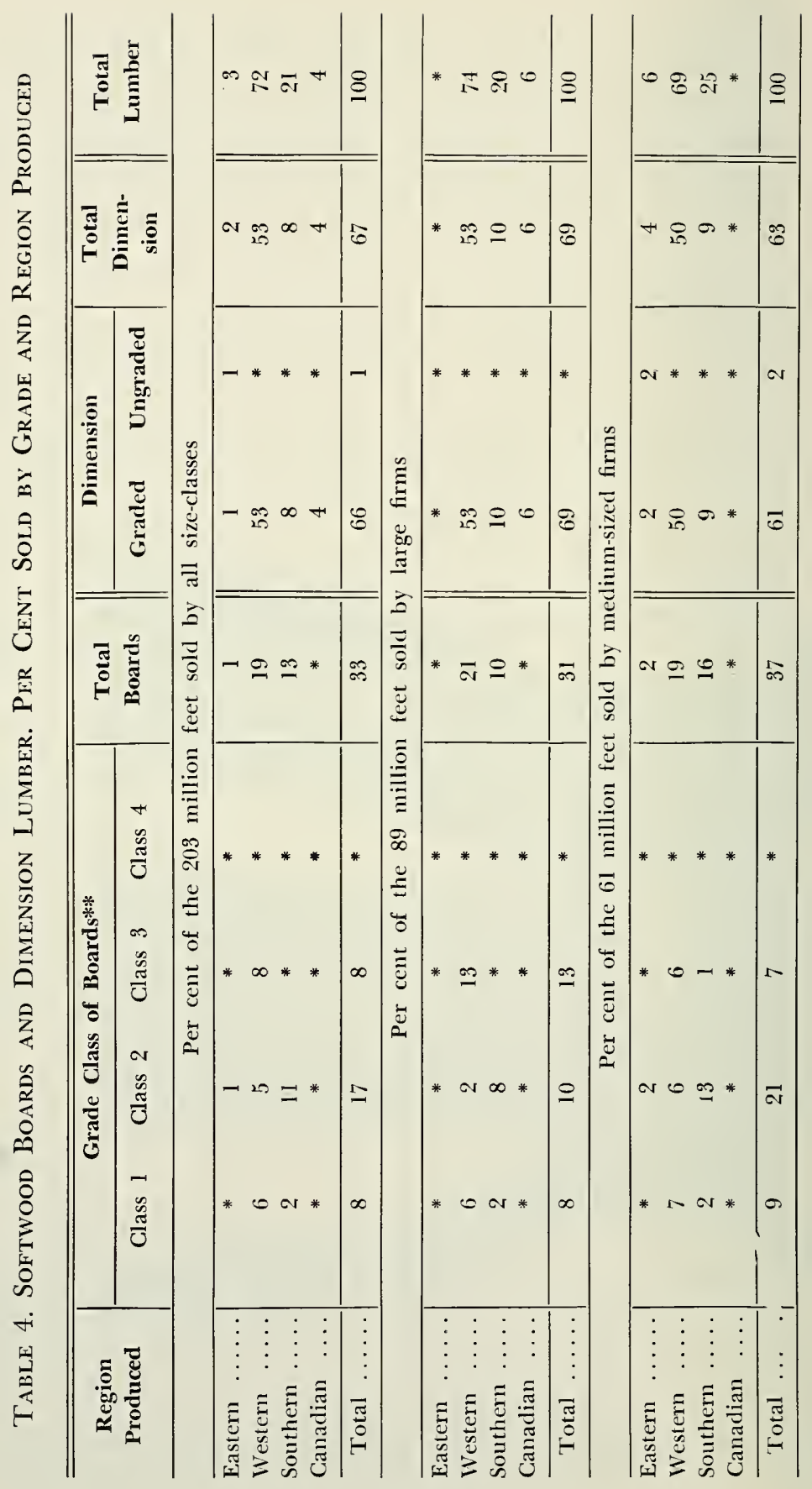




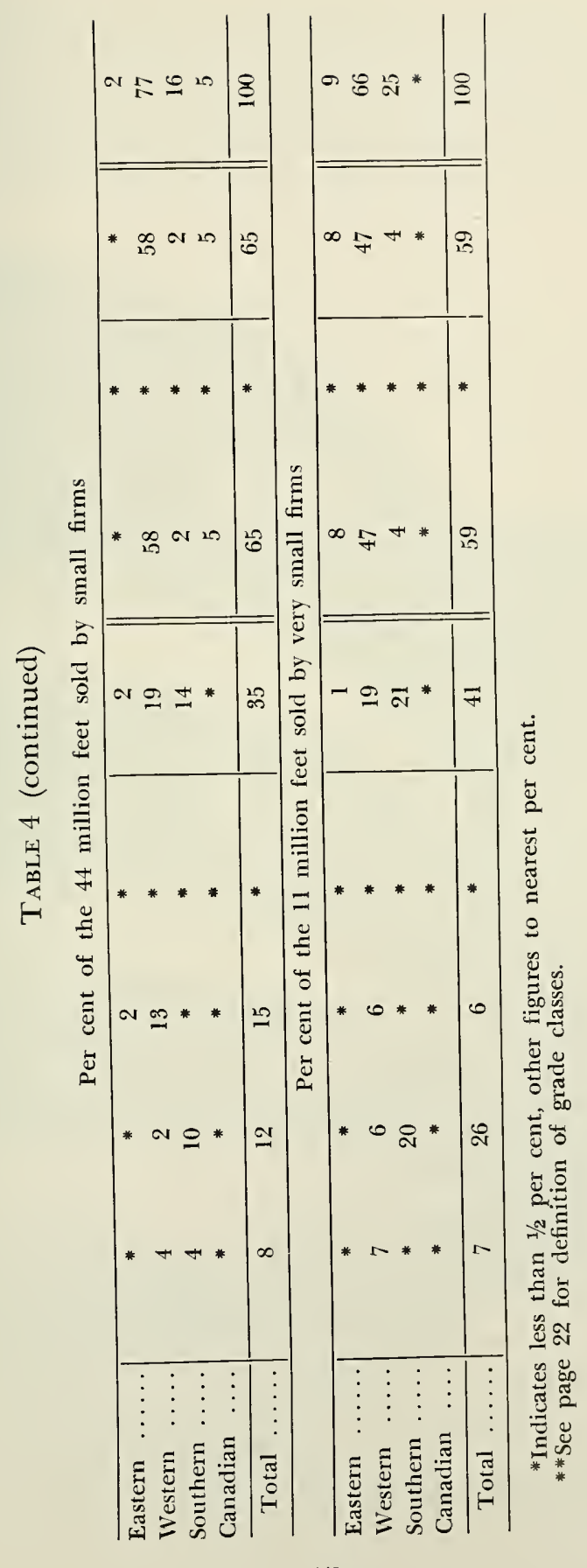


Hardwood lumber accounted for about 10 per cent of the lumber purchased by building contractors and industrial concerns, but only 6 per cent of the lumber purchased by homeowners.

Figure 4 shows the relative volume of lumber sold by the different size classes of firms, and the type of customer buying from these size

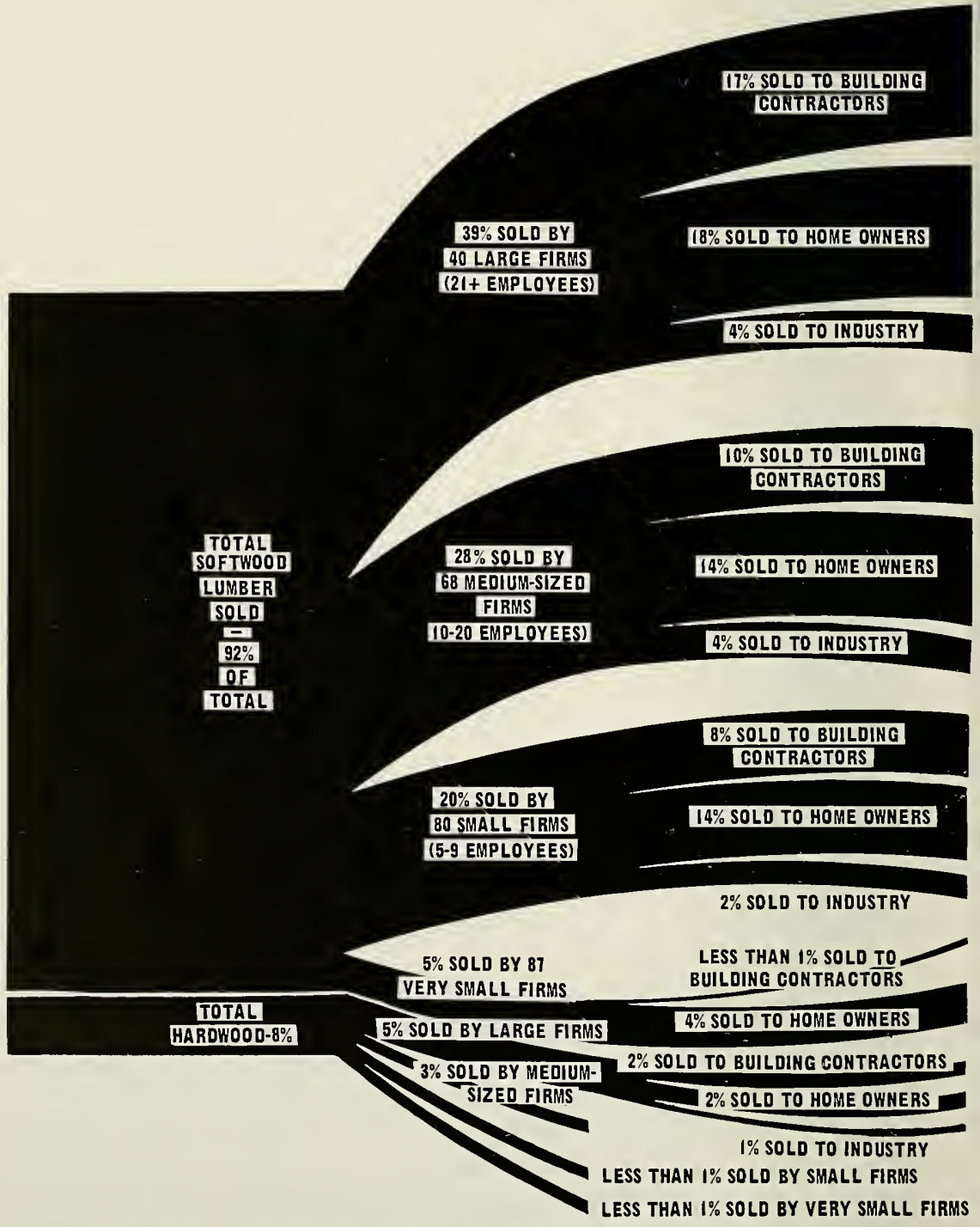

FIGURE 4. Lumber sold, by size class of firm and type of customer. 
classes. Industry bought lumber primarily from the larger yards, perhaps because larger yards are more apt to be located in areas of higher population; these tend to be the more inclustrialized areas. Homeowners bought more lumber than building contractors for each of the four size classes, but the homeowner was particularly important to the very small firm.

\section{Species Carried in Stock}

Retail lumber dealers were asked to indicate which species they carried in stock. Boards and dimension lumber were considered separately. This is not an indication of the relative volume of lumber sold by species. The tables merely show what per cent of the firms stocked certain species, whether they sold large volumes of these or not.

The most commonly stocked species of board were:

\begin{tabular}{|c|c|}
\hline Species & Per Cent of Yards Stocking \\
\hline Oak . & $\ldots \ldots \ldots .81$ \\
\hline Southern pine & $\ldots \ldots \ldots \ldots$ \\
\hline Ponderosa and lodgepole pine & 71 \\
\hline Redwood $\ldots \ldots \ldots \ldots \ldots$ & 63 \\
\hline Western white pine & 59 \\
\hline Douglas-fir . ........... & $\ldots \ldots \ldots$ \\
\hline Birch or maple ...... & 48 \\
\hline
\end{tabular}

The most commonly stocked species of dimension lumber were:

\begin{tabular}{|c|c|}
\hline Species & Per Cent of Yards Stocking \\
\hline Douglas-fir & $\ldots \ldots \ldots \ldots 62$ \\
\hline Western spruce & 59 \\
\hline Western fir (true fir) & 53 \\
\hline Western hemlock .. & 35 \\
\hline Redwood $\ldots . .$. & 29 \\
\hline Southern pine & 26 \\
\hline Canadian spruce & 24 \\
\hline
\end{tabular}

Table 5 shows the per cent of yards which stocked a certain species of lumber, according to size class of the firm. As might be expected, large firms usually stocked a greater variety of species than small firms. Firms usually stocked fewer species of dimension than boards. The maximum, average, and minimum number of species stocked by firms in the various size-classes is given below: 


\section{NUMBER OF SPECIES OF BOARDS STOCKED}

\begin{tabular}{lrcc} 
Size Class & \multicolumn{4}{c}{ Maximum } & Average & Minimum \\
Large $\ldots \ldots \ldots \ldots \ldots$ & 15 & 10 & 4 \\
Medium $\ldots \ldots \ldots \ldots \ldots$ & 11 & 7 & 3 \\
Small $\ldots \ldots \ldots \ldots \ldots$ & 12 & 7 & 2 \\
Very Small . . . . . . & 7 & 5 & 1
\end{tabular}

\section{NUMBER OF SPECIES OF DIMENSION STOCKED}

\begin{tabular}{lccc} 
Size Class & \multicolumn{4}{c}{ Maximum } & Average & Minimum \\
Large $\ldots \ldots \ldots \ldots \ldots$ & 12 & 5 & 2 \\
Medium $\ldots \ldots \ldots \ldots \ldots$ & 8 & 4 & 1 \\
Small $\ldots \ldots \ldots \ldots \ldots$ & 9 & 4 & 2 \\
Very Small $\ldots \ldots \ldots \ldots$ & 4 & 3 & 1
\end{tabular}

No attempt was made to determine how complete a line of products was stocked for each of the species. Often the different species represented different sizes or types of products, so there was still no real choice between species of lumber for a certain use. The possibility of choosing between species can offer decided advantages to the customer. Most customers, however, are relatively unfamiliar with lumber; for this reason the lowest-priced species is often most attractive to them. But for high-quality construction, a wide variety of species is desirable in order to use the species best suited to each application. The lumber dealer who stocks only one or two species may not be offering the customer the best product for a given purpose.

Dealers who buy lumber according to price will accumulate various species due to the fluctuations of lumber prices. This results in a wide variety of species, but not necessarily a wide selection between products. However, in some cases it does, as when the price of Canadian spruce dimension became sufficiently low that dealers began to stock it. This gives the customer an additional species to choose from for framing lumber. For many applications this spruce is satisfactory, but for some uses where high strength is needed, those customers buying the lower priced spruce may be disappointed. On the other hand, the dealer who stocks only Douglas-fir will sometimes force his customers to use a more expensive product than would be required. The larger inventory required to furnish the customer with the most suitable species for a given application may be prohibitive from the dealer's standpoint.

Well-written building codes and well-informed dealers and customers will result in a better matching of the product with its application. 


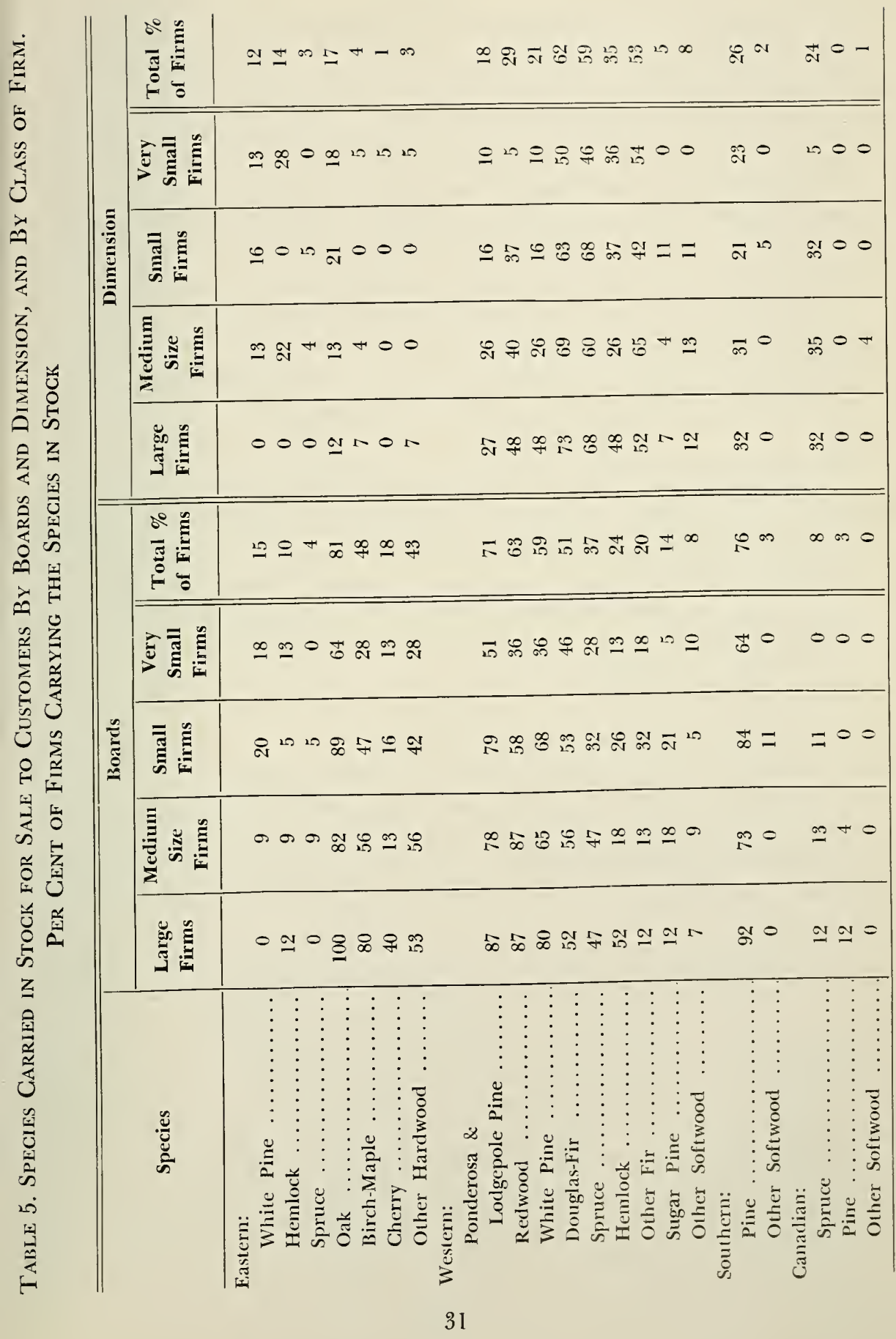




\section{Form and Condition of Lumber When Sold}

The lumber sold by retailers was either rough or dressed. Although a small volume had been surfaced by the retailers (see the section on product transformations by dealers), most of the lumber sold was in the same form as it was when purchased. Nearly all of the softwood lumber, and 60 per cent of the hardwood lumber was sold in the dressed form.

Lumber was sold either in the green, air-dried, or kiln-dried condition. Most of the lumber sold had been kiln-dried, but Southern and Eastern softwoods were exceptions. Nearly 60 per cent of the Southern softwoods and 80 per cent of the Eastern softwoods were sold in airdried condition. About 6 per cent of the hardwoods and a negligible quantity of softwoods were sold in the unseasoned condition.

Table 6 shows the form and condition of lumber when sold by sizeclass of firm and region of origin of the lumber. The bulk of the lumber was sold dressed and kiln-dried. Most of this was Western lumber. It should be pointed out that the term "kiln-dried" does not guarantee that the lumber is lower in moisture content than air-dried lumber. Commercial Western kiln-drying operations usually reduce the moisture content to about 19 per cent. Well-air-dried lumber will often be drier than this. So while a high percentage of Southern lumber was sold airdried, some of this air-dried lumber may be perfectly satisfactory from a technical standpoint.

\section{Length of Dimension Lumber}

Lumber dealers were asked to give the lengths of the dimension lumber they sold. Three lengths were considered: Under 16 feet, nominal 16 feet, and over 16 feet. It was thought that the answers to this question might show that lack of long lengths was a limiting factor for the use of lumber from certain regions, particularily the Southern and Eastern.

Tabulation of the length of softwood dimension lumber by region shows the following, based on 133 million board feet:

\section{LENGTH OF DIMENSION LUMBER}

\begin{tabular}{|c|c|c|c|}
\hline Region & $\begin{array}{l}\text { Less Than } 16 \text { Feet } \\
\quad(\text { Per Cent })\end{array}$ & $\begin{array}{c}\text { Nominal } 16 \text { Feet } \\
\text { (Per Cent })\end{array}$ & $\begin{array}{l}\text { Over } 16 \text { Feet } \\
(\text { Per Cent })\end{array}$ \\
\hline Eastern & $\ldots 81$ & 18 & 1 \\
\hline Western & 43 & 37 & 20 \\
\hline Southern & 67 & 22 & 11 \\
\hline Canadian & 40 & 40 & 20 \\
\hline Average & 47 & 35 & 18 \\
\hline
\end{tabular}




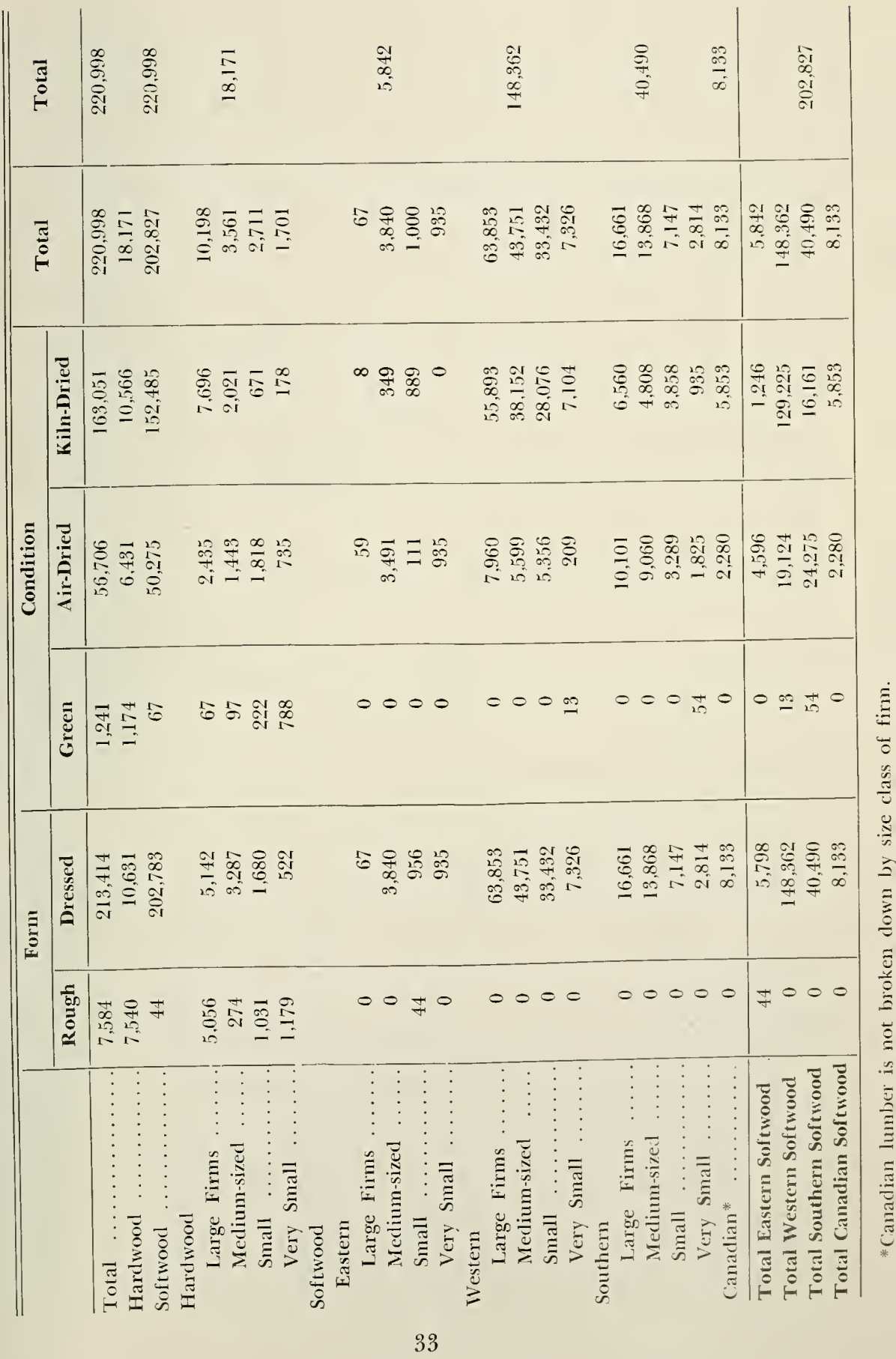


Over half of the dimension lumber sold was 16 feet or over in length. The Southern and Eastern dimension, however, had only a small proportion of pieces over 16 feet in length. In a previous section, on reasons given for purchasing lumber, 8 per cent of the firms indicated that "lengths available" was a factor in determining what lumber they bought. Figure 2 shows that Western softwood lumber comprises 80 per cent of the dimension lumber sold to customers. It appears that the availability of long lengths may be an important reason why Western dimension is preferred.

Long lengths of dimension lumber can be used to reduce construction time, and for this reason are desired by some carpenters. Long pieces are cut in two on the job site. This reduces the number of end cuts needed, since the center cut produces two square ends.

Obviously, certain pieces of framing lumber must be over 16 feet in length, whenever the house design calls for clear spans greater than 16 feet. Except for Eastern softwood, there appeared to be adequate volumes of the long lengths available.

\section{Services Available to Customers}

The retailers in this survey all agreed that they provide a service to their customers. The types of service most frequently offered are listed in Table 7 , along with the percentage of firms offering this service.

Most of the services listed were performed by the majority of firms in all size classes. The very small firms offered somewhat less service, especially in the areas of do-it-yourself and house plans. They also were

Table 7. Services Available to Customers

(Per Cent of Yards Offering the Service)

\begin{tabular}{|c|c|c|c|c|}
\hline \multirow{2}{*}{ Service } & \multicolumn{4}{|c|}{ Yards } \\
\hline & Large & Medium & Small & Very Small \\
\hline Volume Estimates .......... & 100 & 100 & 100 & 90 \\
\hline Cost Estimates $\ldots \ldots \ldots \ldots \ldots \ldots$ & 100 & 100 & 100 & 90 \\
\hline Cutting-up Boards .......... & 100 & 100 & 100 & 85 \\
\hline Building Materials & & & & \\
\hline Price Comparisons ... & 93 & 86 & 100 & 90 \\
\hline Brochures on Wood Use & 86 & 77 & 95 & 66 \\
\hline House Plans ........... & 100 & 91 & 89 & 66 \\
\hline Wood-Technical & & & & \\
\hline Specifications .. & 67 & 95 & 66 & 37 \\
\hline Do-it-yourself Plans & 86 & 91 & 61 & 32 \\
\hline Equipment Rental. & 44 & 46 & 45 & 32 \\
\hline Self-Service $\ldots \ldots \ldots \ldots \ldots \ldots$ & 19 & 12 & 6 & 10 \\
\hline Price-Stamped Lumber . ....... & 0 & 0 & 0 & 5 \\
\hline
\end{tabular}


weak in furnishing brochures on wood use and in giving information about technical specifications for wood.

Other services were listed by those firms which furnished them. The most common was financing or arranging for financing. It was stated by at least one firm that the builders in its particular area used the retail yard as a bank. If they lacked money to build, they bought materials on credit from the retail lumber dealer. If they had the money, they bought materials wholesale or at cash-and-carry lumber yards. Some yards loaned tools to customers. Staplers, shingle cutters, floor nailers, and tackers were loaned out.

Other yards rented equipment to customers. The most common type of equipment rentals were floor sanclers, staplers, floor polishers, fioor nailers, power nailers, caulking guns, and electric saws.

The information dealers passed on to their customers came from numerous associations, manufacturers, and suppliers. Among the more important were:

National Lumber Manufacturers Association

Douglas-fir Plywood Association

United States Gypsum

Weyerhaeuser Company

West Coast Lumbermen's Association

Better Homes and Gardens-Plan Service

National Retail Lumber Dealers Association

National Lumber and Building Material Dealers Association

Southern Pine Association

West Virginia Lumber and Builders Supply Dealers Association

Western Red Cedar Lumber Association

Most of this information is either promotional or direct advertising; this limits its usefulness, in certain instances. However, much of the information is reliable, although it usually is intended to emphasize one group of products.

\section{Use of Credit and Delivery Service by Customers}

Customers either paid cash, bought on credit, or paid for materials in advance. Payment within 30 days or less was considered to be a cash sale. Some retailers objected to this definition of cash, insisting that any sale not paid for immediately was a credit sale. Answers to this question, however, were given with the understanding that payment within 30 days was considered a cash sale. Dealers pointed out that frequently "cash" sales lapsed into "credit" sales through failure of the customer to pay by the end of 30 days. 
This study considered the use of credit by building contractors homeowners, and industry. Payment in advance by all groups was very rare. Sixty per cent of the sales to building contractors was on credit Often the payment awaited the sale of the completed house. Fifty-five per cent of the sales to homeowners was on credit. Much of this was installment plan buying. Industry seldom bought on credit; the data show that 90 per cent of the sales to industry were for cash.

Lumber purchased from retail yards was either delivered to the customer, or not delivered. When lumber was not delivered, the customer made some arrangement to handle the lumber himself. If the yard delivered lumber, it did so either at extra cost or at no extra cost. Most of the lumber was delivered by the retail yards at no extra cost, but almost one-fourth of the lumber sold to homeowners was delivered at extra cost. Less than 20 per cent of the lumber sold was not delivered, and was therefore handled by the customer.

The question of a charge for delivery is an accounting technicality. Some yards maintained that they did not charge for delivery, but they did offer a discount price, or a cash-and-carry price, to the customer who did not require delivery. In some cases there were numerous prices, depending upon the volume of lumber sold, the distance to be delivered, the terms of sale, etc. It is fairly safe to say that the customer pays for the delivery, whether or not there is an extra charge. If there is only one price, it is usually based upon delivery to the job site. Then those customers who handle their own lumber are paying for the delivery, even though they aren't getting it. The growing success of cash-and-carry operations suggests that at least some customers prefer to pay less for the lumber, and handle it themselves.

An attempt was made to determine the maximum distance a retailer will deliver lumber at no extra cost to the customer. Many dealers point out that they did not usually deliver a truckload containing only lumber. The normal truckload contained some higher-value, less-bulky items, and these often had a higher mark-up than lumber, making it profitable to deliver the entire load over a greater distance. The free delivery distances varied between firms from 5 to 100 miles.

At the same time, the dealers were asked to give the minimum value of product which they would deliver at the maximum distance, for no extra cost. It was again pointed out that the maximum distance would depend upon the value of the product. It would not pay to give free delivery, for example, for a truckload of concrete blocks across town, but it would be profitable to haul a truckload of plywood several hundred miles. The minimum value per load ranged from ten to a thousand dollars. 
By taking each firm's maximum distance and minimum value data, it appears that most firms will cleliver $\$ 100$ worth of lumber about 20 miles, or $\$ 200$ worth about 35 miles, or $\$ 300$ worth about 50 miles. This suggests that firms are willing to offer approximately fifteen miles of free delivery per hundred dollars worth of lumber.

An additional consideration is that much smaller values will be delivered within the delivery area, provided that the customer is willing to wait until the yard has a truckload of products to deliver in that general direction.

By dividing the maximum delivery distance into the minimum value of lumber that would be delivered that distance, a factor expressing value of lumber per mile of delivery can be computed. These factors were highly variable between firms. The lowest factor recorded in the survey was $\$ 0.67$ per mile. The firm with this factor would deliver $\$ 10$ worth of lumber a distance of 15 miles. The highest factor recorded was $\$ 20$ per mile. This firm would deliver $\$ 500$ worth of lumber 25 miles. Another firm with the same factor would require $\$ 200$ worth of lumber to deliver 10 miles.

The most common factors and combinations were:

Two dollars per mile- $\$ 50$ worth of lumber for 25 miles, or $\$ 100$ worth for 50 miles.

Four dollars per mile- $\$ 100$ worth of lumber for 25 miles, or $\$ 200$ worth for 50 miles.

Six dollars per mile- $\$ 300$ worth for 50 miles.

The credit and delivery services offered by retail yards were used extensively by most groups of customers. Industry asked for the least credit (only 10 per cent of the sales were for credit) but the most delivery service (98 per cent of sales to industry were delivered). Building contractors and homeowners bought over half the lumber they purchased on credit, and asked for delivery on over three-quarters of it.

\section{General Comments}

Each interviewee was given an opportunity to express himself during and after the interview. Many of the comments made by them are worthy of inclusion in this report. Other comments of a general nature are made by this interviewer, based upon impressions formed during the interviews.

Some retailers felt they needed to apologize for not handling larger volumes of West Virginia-grown lumber, perhaps because they knew the interviewer represented the Division of Forestry at W'est Virginia Unirersity. They pointed out that both West Coast and the Southern pine 
regions have trade associations to aid retailers in marketing lumber, whereas there is no West Virginia softwood association. It was further pointed out that production of local softwoods was uncertain, and quality was variable-usually low. In addition, local woods were not well-dried, and they did not meet the building code requirements in certain areas. Most retailers were well satisfied with West Virginia hardwoods, but they did not stock large quantities of them because hardwoods find limited use in the building trades.

Retailers in West Virginia still sell large volumes of softwood lumber, but some have come to rely less and less upon the revenue from the sale of lumber. Other product lines have become more profitable to handle than lumber; for this reason some retailers handled lumber only as a service to their customers. They depended upon other products to furnish profits for the firm. It was frequently stated that anyone who wanted to buy large quantities of lumber could go to some large cashand-carry firm or some lumber wholesaler. Lumber could be bought from them at near wholesale prices, and for this reason many yards are diversifying. Those that depend primarily on lumber sales are, for the most part, declining. There is a growing fear that modern merchandising will result in business failure of the many yards that fail to change with the times. Price competition is severe, both between retail yards and between other firms which deal in some of the same products.

The competition is sometimes accused of being deceptive. An example cited by one retail dealer in West Virginia illustrates this. For years this dealer has sold A-D plywood to those customers who wanted good-one-face plywood. His competition has begun to sell the lower grade B-D plywood, calling it "good-one-face." Most customers are not aware that this is a lower grade than the A-D plywood, so they buy the lower priced plywood. In order to compete with this deceptive merchandising, this dealer has begun to sell B-D plywood also, as good-oneface.

Another kind of competition of retail lumber yards is the mailorder house. A recent mail-order catalog, for example, contains 250 pages of products of the kind sold by many retail yards. This mailorder house sells hardware, tools, siding, fencing, electrical supplies, wall and ceiling panels, paint, bathroom fixtures, plumbing supplies, heating supplies, tile, fiberglass panels, and appliances. In addition, it sells other products normally thought to be strictly lumber yard products, such as softwood plywood, hardwood paneling, hardboard, insulation, particle board, hardwood strip flooring, doors, windows, and other millwork products. 
In order to compete, some retailers have become involved in the sale of real estate. Some purchase lots, build houses upon them, and then sell the completed house with lot. Others let contracts to builders, with a clause in the contract requiring that the builder purchase lumber from the retail yard. Or they may buy an older house, remodel it using materials from their yard, and then resell the house.

Another competitor of retail yards that has made substantial progress in West Virginia is a pre-cut housing firm. One of the five local offices of this firm located in West Virginia arranges to have pre-cut houses shipped directly from a manufacturer in Pennsylvania to the job site in West Virginia. The pre-cut house arrives in pieces; all the pieces are cut to exact size and numbered. The buyer assembles them by number according to a detailed plan. The saving in construction time is considerable, and relatively unskilled workers can assemble these houses. In 1961 about 150 houses were sold by this firm in West Virginia. These houses contain an average of 8,000 board feet of lumber. This represents over a million feet of lumber that did not go through retail lumber yards.

Another growing menace to lumber yards is the factory-built house, in which entire sections are mass constructed at the factory. The sections are assembled on the job site in several hours. The resulting saving in labor cost is considerable. There are numerous advantages to assemblyline production of houses, among them are mass buying of materials, power nailing, less skilled labor requirements, and use of high production woodworking machines. It appears that factory-built houses may pose a serious threat to the future of retail lumber yards.

It was disconcerting to this interviewer to discover that the managers of retail yards apparently did not have accurate information about the lumber handled by their own firm. Unfortunately, many of the answers were nothing more than approximations. It often appeared that no one in the firm had a reasonably accurate idea of how much lumber was sold during a calendar year.

The answers to the question, "How much lumber did you purchase for resale in 1961?" were far from encouraging. Some managers could not even approximate a value. Others guessed at the number of railroad carloads they probably received in that year, and multiplied this number by the average volume of lumber per car. In some interviews, the manager called in all of top management to discuss how much lumber was probably sold per year, and there were often wide differences between the estimates of different members of the firm. Howrever, the data presented in this report are the best available.

(Conclusions on next page) 


\section{Conclusions}

Retail lumber yards and building material dealers in West Virginia handle over 200 million feet of lumber per year, most of which is Western softwood. Relatively small volumes of Eastern hardwood are marketed through retail yards, hardwoods being of limited use in the building trades. Eastern softwoods were sold by some retailers, but for the most part they were poorly manufactured and seasoned, and not available in the assortment of sizes clesired.

Retailers are becoming complete building materials dealers. Retailing in general is becoming more highly competitive, and the retail lumber trade is no exception. There were few attempts to integrate vertically. Retail yards were almost completely clivorced from sawmills, but some of the more progressive retailers are moving into the construction field, selling completed homes rather than lumber. Horizontal integration is present, but not on the scale one might expect. Several firms owned several to many retail outlets, and some purchased collectively for all their units.

The lumber retailer continues to play an important role in the movement of lumber from producer to consumer. A wide assortment of materials is made available by the retailer in small quantities for the consumer. The retailer also explains what materials to buy, and how to use them; he delivers the materials to the job site, and often offers credit.

Rising construction costs have resulted in attempts to by-pass the lumber retailer. Pre-cut and pre-fabricated houses are built in large numbers at a central location by firms which purchase lumber wholesale. Large-scale contractors build entire subdivisions with lumber purchased wholesale in carload lots. Thus, considerable proportions of new housing do not need or use the retailers' services.

Retailers are increasing sales to do-it-yourselfers and for home repairs, remodeling, and enlarging. Some have begun to give the impression of being complete supermarkets for the amateur handyman.

The future for the old-line lumber yard as such does not appear rosy. But the modern building materials retailer, using modern merchandising, will do much better.

\section{Ch 827}




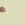


